\title{
A subjetividade, o Fora e a cidade: repensando o sujeito, o espaço e a materialidade
}

\author{
Carlos Antonio Cardoso Filho ${ }^{\star}$ \\ Universidade Federal do Rio Grande do Sul, Porto Alegre, RS, Brasil
}

\begin{abstract}
Resumo
A filosofia Kantiana ao introduzir o tempo como principal operador de subjetivação, concebe o espaço como sendo passivo e mecânico. Propomos pensar uma subjetividade constituída por exterioridades espaciais e materiais ativas e não-lineares. Partindo da ideia do Fora em Deleuze e Foucault, e das teorias da "cognição estendida", exploramos uma "subjetividade distribuída", na qual o sujeito não é composto apenas por seu corpo ou interioridade, mas também pela materialidade, espaço e não-humanos. Abordamos processos de externalização formadores da subjetividade para repensar a relação entre cidade e subjetividade distribuida, abandonando a ideia de um espaço de circulação de sujeitos para compor agenciamentos que mesclam subjetividade e cidade e um composto indiscernivel.
\end{abstract}

Palavras-chave: subjetividade; cidade; espaço.

\section{Subjectivity, the Outside and the city: rethinking subject, space and materiality}

\begin{abstract}
The Kantian philosophy by introducing time as the main operator of subjectivity production, assumes space as passive and mechanical. We propose to think a subject made up of spatial externalities and active and nonlinear materials. Starting from the idea of the Outside in Deleuze and Foucault, and theories of "extended cognition", we explore "a distributed subjectivity", in which the subject is not composed only of his own body or interior, but also by the materiality, space and non-humans. We approach the externalization processes that make subjectivity to rethink the relationship between city and distributed subjectivity, abandoning the idea of a circulation space of subjects, to compose assemblages that mix subjectivity and city and indiscernible compound.
\end{abstract}

Keywords: subjectivity; city; space.

Desde Kant o pensamento acerca da subjetividade coloca a temporalidade como um operador central de subjetivação. É no e pelo tempo que os sujeitos são de um ou de outro modo constituídos. O espaço desempenha um papel secundário, sendo da ordem de uma exterioridade considerada enquanto materialidade inerte e mecânica. Esta divisão entre tempo e espaço acaba reproduzindo a dicotomia sujeito/objeto que separa mente e corpo, materialidade e subjetividade. Reintroduzir o corpo na subjetividade, e vice-versa, implica em outro modo de pensar a divisão entre sujeito e mundo, deslocando e até mesmo apagando seus limites (VARELA; ROSCH; THOMPSON, 1993). O que acontece com a subjetividade quando a pensamos em meio a um espaço que não é nem mais cartesiano, linear e mecanicista? $\mathrm{O}$ que acontece ao sujeito quando não é apenas corporalizado, mas concebido em meio a uma materialidade tão complexa quanto a própria subjetividade?

Pensar a subjetividade do ponto de vista de um espaço não-linear, isto é, de um espaço que não é nem métrico, extensivo ou mecânico, mas intensivo, implica na constituição de um sujeito que não é nem individual, nem coletivo, mas "distribuído". Em outras palavras, a subjetividade não se encontra mais atrelada nem a uma interioridade, nem a um corpo individual. Passa a ser algo que circula, um composto de forças, ações e cognições que atravessa diversos corpos, humanos e não-humanos ao

\footnotetext{
^Endereço para correspondência: Universidade Federal do Rio Grande do Sul, Programa de Pós-Graduação em Psicologia Social e Institucional. Rua Ramiro Barcelos, 2.777 - sala 212. Santana - Porto Alegre, RS, Brasil. CEP: 90035-003. E-mail: carloscardosof@gmail.com
}

mesmo tempo. Se a subjetividade se encontra distribuída pelo espaço, torna-se necessário repensar a relação que estabelece com a cidade, uma vez que esta deixa de ser um simples meio ou espaço externo no qual a subjetivação acontece e passa a ser um elemento constituinte da própria subjetividade. É a relação entre a subjetividade distribuída e a cidade que propomos explorar neste texto.

\section{Subjetividade e Tempo}

A distinção cartesiana entre corpo e alma baseia-se em uma assimetria fundamental entre os modos de funcionamento de dois termos: divisão e unidade. O corpo "não é formado e composto a não ser de certa configuração de membros e outros acidentes análogos; e a alma humana, ao contrário, não é composta de quaisquer acidentes, mas é uma substância pura" (DESCARTES, 2000, p. 243). Afirmar que o corpo é formado por acidentes o coloca como algo não necessário. Uma vez que é divisível, que suas partes podem ser cortadas, separadas, modificadas, em um processo constante de transformação, o corpo apresenta uma unidade frágil que pode ser quebrada a qualquer momento pela ação de forças físicas e mecânicas. A alma, por sua vez, é unitária. Como pura substância não possui partes, nem pode ser parte de alguma outra substância. É o indivíduo perfeito, fechado sobre si mesmo e capaz de manter sua identidade perante qualquer transformação.

Mais do que uma separação entre matérias, apesar de sua implicação direta para o pensamento da materialidade, o cogito cartesiano é possível através da afirmação de 
diferentes papéis dados ao corpo e à alma. Um corpo divisível e puramente mecânico não pode se constituir como uma fonte de certeza para o conhecimento, dado que se transforma constantemente, podendo alterar-se completamente de um instante a outro. Deve existir algo de imutável, permanente e constante em relação ao qual tudo o mais possa ser comparado. A unidade da alma constitui a medida que serve de parâmetro para o julgamento de todas as outras verdades, unidade que é fundamentada na bondade e na existência de Deus (DESCARTES, 2000).

O cogito é uma ação pela qual uma existência indeterminada - "eu sou" - é determinada pela determinação "eu penso". Surge uma existência determinada como pensante: penso, logo sou (como coisa que pensa). É uma determinação instantânea, onde há pensamento há ser pensante. A unidade da alma enquanto certeza constitui-se nessa determinação. Mas se a alma não é divisível no espaço, por não ser extensa, o mesmo se daria no tempo? A determinação do cogito é instantânea, mas acontece apenas uma vez, ou é necessário que se dê a cada instante? E o que garante que a cada instante um outro Eu não seja afirmado, distinto daquele outro Eu que era um instante atrás? Para Descartes, é Deus quem garante a unidade da alma e da subjetividade na sucessão de instantes do tempo (DELEUZE, 2006).

Com Kant, contudo, a concepção de um cogito instantâneo que se desdobra em um tempo concebido como sucessão de instantes, e cuja unidade é garantida por um Deus, não é suficiente. Primeiro, como o determinado, "eu penso", pode incidir diretamente sobre o indeterminado, "eu sou"? De acordo com Deleuze (2006), a crítica kantiana se dá na problematização dessa determinação, pois é necessário esclarecer como o indeterminado pode ser determinado, como ocorre essa transformação. "Kant acrescenta, pois, um terceiro valor lógico: o determinável, ou, antes, a forma sob a qual o indeterminável é determinável (pela determinação)" (DELEUZE, 2006, p. 132). O determinável é o tempo, isto é, o tempo enquanto forma que dá a estrutura necessária para que o eu existente passe a ser um eu que pensa. Mas, para que possa colocar o tempo nessa posição é necessário que Kant realize um duplo deslocamento e redefina tanto tempo quanto espaço.

De acordo com Deleuze (1997), na filosofia antiga o tempo encontrava-se subordinado ao movimento circular do mundo, era a medida de um movimento que lhe precedia, de um deslocamento ao redor do eixo central da ordem cósmica. Kant opera a inversão dessa perspectiva, e subordina o movimento ao tempo. O tempo se esvazia, sai de sua ordem cíclica para tornar-se uma linha reta que define a sucessão de instantes (ao invés de por eles ser definido). Da mesma maneira o espaço deixa de ser definido pela simultaneidade ou coexistência. Sucessão, simultaneidade e permanência passam a ser modos do tempo. Tudo o que está no tempo muda, mas o próprio tempo não muda, é a "forma imutável da mudança e do movimento” (DELEUZE, 1997, p. 35).

É nesse sentido que o tempo, como forma imutável que já não podia ser definido pela simples sucessão, aparece como a forma de interioridade (sentido íntimo), ao passo que o espa- ço, que já não podia ser definido pela coexistência ou simultaneidade, aparece por sua vez como forma de exterioridade, possibilidade formal de ser afetado por outra coisa enquanto objeto externo (DELEUZE, 1997, p. 40, grifo do autor).

Tempo e espaço passam a ser "formas" pelas quais a interioridade e a exterioridade são estruturadas. Ou melhor, ambos constituem a interioridade do sujeito, uma vez que em Kant não há mais acesso direto a um mundo exterior, à coisa em si. O que os define, no interior da subjetividade, é a capacidade de o espaço representar uma exterioridade à interioridade, e o tempo de colocar a interioridade em relação consigo mesma, isto é, o tempo é o modo pelo qual a interioridade pode afetar a si mesma, operando a síntese de todos os "eus" que se sucedem no tempo em um $\mathrm{Eu}$ transcendental que os unificaria, constituindo a subjetividade (DELEUZE, 1997, 2006).

$\mathrm{Na}$ medida em que funda a subjetividade na forma do tempo e na capacidade da interioridade de se autoafetar, Kant insere uma rachadura no $\mathrm{Eu}$, pois torna-se necessário distinguir o sujeito empírico do sujeito transcendental. O eu empírico existe "no" tempo, sendo produzido a cada instante, é passivo e receptivo, a quem os fenômenos são apresentados. A passividade do sujeito empírico refere-se à sua incapacidade de síntese, não sendo capaz de criar "representações" (reapresentações) e "recognições". Para isto é necessária a unidade de uma consciência, do eu penso. Diferentemente de Descartes, o que garante essa unidade, especialmente na sucessão dos instantes, não é Deus, mas o tempo enquanto "forma", ou seja, o sujeito transcendental. Temos então dois "eus": um eu empírico produzido a cada instante, e um Eu transcendental que é a própria estrutura da subjetividade dada como forma do tempo e do espaço, forma imutável da mudança. A cada instante um eu empírico recebe apresentações, enquanto o Eu transcendental as sintetiza em representações (DELEUZE, 2006).

Quando Kant afasta Deus de seu papel determinante e instaura a rachadura no Eu, separando-o entre um eu puramente passivo e receptivo, e um Eu ativo, sintético e unitário, é nessa rachadura que, de acordo com Deleuze (2006) já se prefigura a morte de Deus. Pois enquanto há $\mathrm{Eu}$, enquanto há sujeito como entidade unitária e idêntica a si mesma, há Deus, que é o sujeito último e representante de toda ontologia baseada na identidade, no mesmo, na recognição e na oposição sujeito-objeto que lhe é fundamental. A rachadura é, contudo, fechada, seja no domínio da prática, seja pela concordância das faculdades no sujeito. O que Kant desenvolve é a ideia de uma subjetividade fundada e constituída na temporalidade. Esta ideia será incessantemente retomada posteriormente, tanto a favor e contra Kant, tornando-se um dos pontos centrais de problematização da subjetividade moderna.

Tanto o espaço quanto o tempo, na filosofia kantiana, são estruturas fundamentais da experiência. Mas por que apenas o tempo dá a estrutura fundamental da subjetividade? Por que o espaço não pode servir, também, como "forma" de determinação do sujeito? Como vimos, o es- 
paço é a forma de exterioridade, que permite ao sujeito entrar em contato com todo o mundo de objetos que não são ele mesmo. Do que é feita essa exterioridade?

Com Descartes, Galileu e Newton e o desenvolvimento das ciências modernas, a matemática assumiu o papel de linguagem da natureza. As verdades matemáticas passam a ser verdades da própria natureza, mesmo que esta, em sua perfeição matemática, tenha sido criada e estabelecida por Deus, é a própria natureza, através da matemática, que deverá revelar suas verdades e não mais Deus, que deixa de ser o protagonista no cenário do saber. Se a matemática é o modo pelo qual a natureza pode ser decifrada, a geometria euclidiana, tomada como modelo do espaço pela física newtoniana, torna-se então, literalmente, o espaço dessa nova natureza. Subjacente a estes desenvolvimentos encontramos a crença em um mundo racional e organizado, capaz de ser analisado e compreendido, cujos elementos são guiados por leis universais, como a órbita dos planetas e o movimento regular dos astros.

Hume colocou em questão essa regularidade do mundo. O homem é um composto de sensações, tudo aquilo se que chama de mente ou de matéria não passa de um agregado de sensações. Como tal,

[...] quem garante que há um mundo de objetos sólidos permanentes e existentes? Tudo o que conhecemos são nossas próprias sensações de tal mundo. Repetidas sensações de uma cadeira não provam que uma cadeira realmente exista. Tempo e espaço nada mais são do que uma maneira e ordem em que as ideias nos ocorrem. Similarmente, a casualidade nada mais é do que uma conexão de ideias habitual. Nem espaço, tempo ou casualidade são uma realidade objetiva. Somos iludidos pela força e firmeza de nossas sensações em acreditar em tais realidades. A existência de um mundo externo com propriedades fixas é uma inferência sem garantia; a origem de nossas sensações é inexplicável. Se surgem a partir de objetos externos, da própria mente ou de Deus, não podemos dizer (KLINE, 1982, p. 74, grifo do autor, tradução nossa).

A crítica de Hume aplica-se facilmente às ciências, que por sua natureza indutiva dependem de generalizações a partir de uma quantidade finita de casos. A verdades matemáticas, por sua vez, são derivações lógicas de axiomas, especialmente no caso da geometria, e não dependem de nenhuma generalização. Hume não nega a necessidade lógica das derivações, contudo, questiona os próprios axiomas, que são baseados também em sensações e nas ideias que as acompanham. Uma vez que os teoremas podem sempre ser reduzidos aos axiomas, a verdade matemática também é incerta. Portanto, nada garante que as verdades da matemática, e das ciências que nela se apoiam, realmente sejam verdades do mundo e a natureza, e nada garante que sequer exista um mundo, uma natureza ou realidade fora de nossas sensações (KLINE, 1982).

Foi o problema colocado por Hume que Kant (2000) buscou resolver em sua Crítica da Razão Pura. Para Kant, não temos acesso direto ao mundo, à coisa em si. Apenas fenômenos e sensações constituem nossa experiência. Mas, diferentemente de Hume, para que a experiência faça sentido é necessário que algo a estruture e organize as sensações. O tempo e o espaço de Kant são as duas formas pelas quais toda experiência humana é estruturada. Tempo e espaço são estruturas da subjetividade humana, uma vez que as coisas em si não são diretamente acessíveis podemos concebê-las apenas através desse filtro subjetivo (KLINE, 1982).

Mesmo afirmando um sujeito sem a capacidade de representar o mundo tal qual é, Kant ainda afirma as verdades da matemática e da ciência, e para isso distingue entre dois tipos de conhecimentos: juízos sintéticos a priori e a posteriori. Um juízo analítico é aquele em que o predicado já está incluído no sujeito, isto é, o que é afirmado já faz parte da coisa. Por sua vez, em um juízo sintético o predicado tem relação com o sujeito, mas não está contido neste. O conhecimento é composto por juízos sintéticos, pois acrescentam algo ao que já é conhecido. Os juízos a posteriori, baseados na experiência, são todos sintéticos, o que não garante que sejam verdadeiros. Todos os juízos necessários são a priori, independentes da experiência. É possível que existam juízos que acrescentem ao nosso conhecimento e que sejam necessários, isto é, que sejam juízos sintéticos a priori? Kant colocou neste nível muitas das verdades matemáticas. Toda a geometria Euclidiana e a física Newtoniana foram incluídas na forma do espaço que constitui a estrutura subjetiva. Com esse movimento, Kant não apenas reconstituiu o lugar da verdade matemática, mas a ligou diretamente às condições de possibilidade de toda experiência humana. Negar a verdade da geometria Euclidiana seria o mesmo que negar o próprio espaço (KLINE, 1982). A forma de exterioridade em Kant, coincide com a geometria Euclidiana e a física Newtoniana. A exterioridade é concebida então como espaço métrico e extensivo, matéria sujeita a leis mecânicas e lineares, pura necessidade sujeita às leis da física e da geometria, reservando apenas à interioridade a liberdade, vontade e criatividade.

$\mathrm{O}$ vitalismo, em suas mais diversas formas, constitui-se em uma estrutura parecida. Não é mais tanto o sujeito ou uma interioridade humana que é a fonte da criação, mas a própria vida, enquanto força que não pode ser reduzida à simples aplicação ou obediência a leis físicas. Em outras palavras, a distinção é colocada entre espaço/ matéria inorgânica de um lado, e vida de outro. Se a subjetividade é fonte de criação isto se dá porque é, antes de mais nada, um ser vivo, e como tal não pode ser compreendido apenas pelas leis da física. A matéria inorgânica por si só não cria nada (BENNETT, 2010).

Em Kant já encontramos um precursor do vitalismo, em sua concepção de Bildungstrieb, que poderia ser traduzida como "impulso formativo", um princípio capaz de organizar a matéria. Sendo completamente inerte e mecânica, a matéria é incapaz de se auto-organizar, não pode dar origem, sozinha, aos seres vivos, que são formas extremamente complexas. A vida poderia existir unicamente sob tal impulso formativo, com o homem sendo seu pináculo. O vitalismo é uma versão menos teológica e antropológica do Bildungstrieb kantiano, mas que se apoia na mesma concepção de matéria (BENNETT, 2010).

Fractal, Rev. Psicol., v. 28 - n. 2, p. 242-251, 2016 
Apesar do foco dado a Kant, o que queremos problematizar aqui é a distinção que coloca o sujeito quase que inteiramente do lado do tempo e da vida, em detrimento do espaço e da matéria. Qualquer pensamento que considere o espaço e a matéria como puramente extensivos e mecânicos, acaba recaindo na distinção kantiana, que se alinha com o mais antigo antropomorfismo. O que nos interessa saber é o que acontece à subjetividade quando esta é concebida em meio a um espaço não-euclidiano, que não é mais nem métrico nem extensivo, mas intensivo, e uma matéria que não é nem mecanicista nem inerte, mas não-linear, indeterminada e "ativa", plenamente dotada de agência, sujeita aos mesmos processos que o vitalismo reserva exclusivamente à vida. Um "materialismo vitalista", como propõe Bennett (2010). Em outras palavras, o espaço e a matéria podem ser operadores da subjetividade, do mesmo modo que o tempo? Podemos pensar em um espaço e em uma matéria capazes de se constituir uma subjetividade por sua "exterioridade", um sujeito, literalmente, "do lado de fora"?

\section{A subjetividade e o Fora}

A subjetividade, tal como é concebida por Deleuze (2005b) a partir da obra de Foucault, constitui-se como uma dobra, espécie de linha ou relação que se volta sobre si mesma. É uma linha do "lado de Fora". O Fora pode ser entendido como uma reserva, um aglomerado pré-individual de forças que ainda não foram agenciadas. Uma força é uma ação, ou, mais precisamente, é qualquer ação que entra em relação tensa e não determinada com outra ação, tentando direcioná-la. A esta relação de forças Foucault dá o nome de poder. A subjetividade é formada quando uma força em um movimento recursivo afeta a si mesma.

Em uma relação de forças cada ação sempre tenta determinar outra, podendo ter sucesso ou resultados imprevistos. A indeterminação é a presença do Fora, deste fluxo constante de forças que sempre pode mudar de direção no último instante. É ao final da ação que o Fora pode ser esgotado e determinado, tornando-se um indivíduo, um sujeito ou um objeto. Contudo, como argumenta Simondon (2008), essa individuação nunca se esgota completamente, uma ação nunca deixa de ter consequências imprevistas ou desdobramentos em uma cadeia causal longa e complexa. O Fora nunca é realmente eliminado nem atualizado. Em uma relação de poder o Fora é colocado em jogo, fazendo com que uma força afete outra, na medida em que sempre tenta direcionar e governar outra a força. A subjetividade é um modo específico de constituição no qual uma força, ao invés de agir sobre outra, age sobre si mesma.

Neste sentido a capacidade de uma força de se autoafetar não é diferente da temporalidade em Kant, pois é pelo tempo que o sujeito pode afetar a si mesmo e constituir-se enquanto temporalidade. No entanto, a subjetividade enquanto dobra difere da subjetividade kantiana (e pode-se dizer, também, de toda subjetividade interiorizada, racional, fundada na consciência individual, isto é, o sujeito do conhecimento) em dois pontos fundamentais. Primeiro, a subjetividade nunca constitui uma verdadeira interioridade. Ao dobrar o lado de Fora, como uma linha ou tecido, é formada uma invaginação, um declive, que cria um espaço interior cujos limites são feitos do próprio fora, para o qual nunca há um fechamento completo. $\mathrm{O}$ Eu permanece rachado, diretamente aberto às forças do fora. A subjetividade constitui um desvio do fora, complexificando a rede de forças formada em um determinado momento (DELEUZE, 2005b).

Uma segunda distinção, que é muito mais evidente em Foucault do que em Deleuze, concerne à natureza das forças (CARDOSO FILHO, 2011). Em Kant a capacidade de autoafetação estava diretamente atrelada ao tempo. Com Foucault, por sua vez, uma força não é qualificada, pois nunca possui uma constituição pré-determinada. Uma força ou relação de poder pode ser tanto temporal quanto espacial, biológica, linguística, mística, tecnológica, entre outras. Isto quer dizer que, diferentemente de Deleuze (2005b), Agamben (2002) e outros autores, em Foucault não pode existir algo como um biopoder opondo-se a uma biopotência, ou uma vida nua e contraposição uma vida plena. Assumir esta distinção implicaria em considerar o poder ligado a uma determinada origem ou matéria específica, como a vida, isto é, um biopoder que limitaria as forças vitais, contra uma biopotência capaz de tornar a vida num foco de resistência. Contudo, a vida, assim como a loucura, o crime ou a sexualidade, não pré-existe à relação de poder. Não há uma substância dotada de propriedades à qual seria aplicada uma força contra ou a favor de sua "natureza própria" ou essência. Não há sexualidade ou vida que serão dominadas ou libertadas pelo poder. A própria vida é resultado de uma relação de forças, e só pode ser referida dentro desta relação. O poder, em si, não é nem dominação nem libertação, tudo depende da relação de forças que constitui.

Este "vazio" presente nas forças não qualificadas e indeterminadas em Foucault é que nos permite escapar ao vitalismo e pensar outras formas de subjetivação que não estejam ligadas a uma matéria ou forma específica. Ou melhor, que nos permite pensar na própria matéria não-humana e no espaço como determinantes da subjetividade. Pois na medida em que a subjetividade é uma dobra, por que esta dobra haveria de estar necessariamente ligada a "um" corpo? Uma dobra não poderia atravessar muitos corpos ao mesmo tempo, humanos e não-humanos? Dado que as forças do fora que constituem a subjetividade não são qualificadas, não precisamos mais nos prender a uma matéria ou forma específica, como tempo, vida e linguagem, e podemos pensar toda a heterogeneidade de elementos que entram na relação subjetiva. Devemos então considerar o fora como potência capaz de criar outras materialidades e espaços, compondo o que chamaremos de "subjetividade distribuída".

\section{Espaço, agencia material e cognição distribuída}

A subjetividade distribuída será considerada a partir de sua relação com a memória e cognição, especialmente nos meios pelos quais estas duas funções - que, em geral, são consideradas as mais íntimas e próprias do ser humano - são externalizadas, ou melhor, em que já são exteriores antes mesmo de serem humanas. Cognição e 
memória, como veremos, são processos encontrados na própria matéria, dado que ao mesmo tempo em que são internalizados, continuam a operar fora do homem. A cidade, foco final deste trabalho, deixa de ser um mero meio indiferente pelo qual o sujeito circula, e passa a ser, literalmente, parte de sua subjetividade, constituindo zonas de indiscernibilidade onde não é mais possível distinguir sujeito e cidade.

A noção de "fenótipo estendido", desenvolvida por Dawkins (2008), nos permite estabelecer um paralelo entre o processo de externalização nos seres vivos e o processo de subjetivação. ${ }^{1}$ Ao contrário das perspectivas mais tradicionais no campo da biologia, para Dawkins (2008) a evolução não se dá nem ao nível dos grupos, nem dos indivíduos, mas ocorre em um nível mais abaixo, sobre aquilo que denomina replicantes, como os genes.

O fenótipo é a expressão de um determinado genótipo, o que geralmente significa que os genes são responsáveis pelo desenvolvimento e formação de uma determinada característica morfológica ou comportamento. O que Dawkins (2008) propõe é não restringir o fenótipo a essas características, englobando também o que por elas é produzido. Por exemplo, se o comportamento de construir um formigueiro possui um determinante genético, este deveria compor o fenótipo da formiga. Por "determinante genético" deve-se entender que um determinado gene entra uma relação causal extremamente longa e complexa com genes e outros fatores externos e internos ao organismo, produzindo um fenótipo ao final desta relação. Portanto, um gene, por si só, nunca é determinante de nada, ele só terá um valor dependendo da relação muito complexa na qual está inserido.

O deslocamento da evolução ao nível do replicante, ao invés do grupo e do indivíduo, permite que o fenótipo estendido seja melhor compreendido. No caso do formigueiro, ele é construído por milhares de indivíduos. Ou seja, inúmeros indivíduos podem compartilhar o mesmo fenótipo, construindo-o através de gerações, da mesma maneira que um organismo que construa casas de barro sazonalmente possui muitos fenótipos, pois cada casa é como se fosse um exoesqueleto ou uma carapaça, ainda que temporária e fixa.

Traçando um paralelo com a subjetividade, se os replicantes forem considerados como as forças do lado de fora, e o fenótipo a dobra constituída, teremos um sujeito que é composto tanto por elementos individuais, quanto coletivos, que podem ser feitos de linguagem, órgãos e matéria inorgânica, que ultrapassam os corpos individuais. Nas ciências cognitivas encontramos dois modelos, de certo modo opostos, que permitem pensar uma cognição nos termos propostos, ao mesmo tempo distribuída, individual e coletiva.

Uma perspectiva similar é adotada pelas noções de “cognição estendida" (CLARK; CHALMERS, 2002), "cognição distribuída" (HUTCHINS, 1995) e "engajamento material” (MALAFOURIS, 2013), que consideram a mente e a cognição como processos que não se

${ }^{1}$ Sem, contudo, adotar a visão extremamente adaptacionista de Dawkins (2008) e outros autores ligados à sociobiologia e psicologia evolutiva. limitam ao cérebro ou ao corpo, constituindo-se através dos espaços e elementos materiais que os compõem. Em outras palavras, a materialidade não é apenas uma reserva de ferramentas e dispositivos passivos externos que auxiliam a cognição internalizada de um sujeito ativo. Ao contrário, a cognição não se daria como tal sem a participação "ativa" de tais elementos. A utilização de um livro, de um computador ou de simples pedras para contar participam da mente da mesma maneira como o corpo, hormônios e neurônios. Sem a presença de tais elementos, determinadas formas de pensar e ser simplesmente não seriam mais possíveis.

Clark e Chalmers (2002) apresentam o caso de duas pessoas que tentam lembrar o endereço de um museu. A primeira para por um instante, consulta a sua memória e lembra do endereço. A segunda pessoa possui Alzheimer, o que a faz sempre carregar consigo um bloco de notas que consulta para recordar o endereço do museu. Em ambos os casos, afirmam os autores, ocorreu um processo cognitivo equivalente, pois os dois sujeitos realizaram a mesma operação de consulta à memória para recordar uma informação. A diferença se dá no fato de que a mente de um se limitou a seu aparato neurológico, enquanto a mente do outro incluiu o bloco de notas como dispositivo de memória externo. Sem a presença do bloco de notas o processo cognitivo de "lembrar do endereço do museu" jamais poderia ter ocorrido para o segundo sujeito.

Pode-se afirmar que lembrar utilizando apenas suas próprias lembranças, sem a necessidade de nenhum aparato externo é um ato cognitivo "mais verdadeiro" do que daquele que o utiliza. Quando o bloco de notas estiver inacessível o sujeito será incapaz de acessar sua memória, coisa que não aconteceria em uma mente em seu estado "natural", isto é, internalizada. Mas se dispositivos de memória externos são tão úteis é porque esquecemos de inúmeras coisas, mesmo sem a presença de nenhuma doença degenerativa. Do mesmo modo que um bloco de notas pode ser destruído, nosso cérebro pode ser danificado, levando à perda de memórias. A presença de um elemento externo em um processo cognitivo tem implicações diversas de um processo exclusivamente interno (se é que há alguma cognição que seja completamente desprovida de externalidade), já que em determinados momentos tais processos podem coincidir, como foi o caso da lembrança do endereço, enquanto em outros podem diferir, o que não os tornam menos cognitivo.

Não é difícil conceber que o "conteúdo" de um pensamento possa estar armazenado no exterior do corpo e do cérebro, como uma ideia escrita em uma folha de papel. O que Clark e Chalmers (2002) e Malafouris (2013) afirmam é que nossos "estados" e "processos" também se encontram externalizados em coisas e objetos. A materialidade passa a constituir uma "externalidade ativa", dotada de agencia, capaz de processar e modificar o pensamento. Uma folha de papel, um bloco de notas e outras superfícies de inscrição similares são tradicionalmente consideradas como substratos passivos, matéria morta, sobre os quais a ação humana se impõe. Mas o simples fato de um bloco ser organizado em páginas, podendo ter linhas, datas e ou- 
tros elementos mnemônicos, "já impõe" um determinado modo de organização ao pensamento. Isto é, por sua composição própria o bloco "age" junto com os outros elementos, humanos ou não, que participam a cognição.

Portanto, o próprio espaço já constitui um modo ativo a cognição. Primeiro, a nossa experiência corpórea em um espaço nos dá as estruturas cognitivas para pensar o tempo, e outras noções, através de um jogo metafórico. Partindo dos trabalhos de Lakoff, Johnson e Nuñez, Malafouris (2013) mostra como a nossa experiência do tempo é moldada por nossa estrutura corporal. Expressões que colocam o passado "atrás", o futuro "na frente" e o presente "aqui", apoiam-se todas em metáforas que espacializam o tempo. Geralmente atribui-se a Newton e Descartes a ideia de um tempo espacializado, mas pode-se dizer que tal concepção nada mais é do que uma extensão de nossa experiência em "ter um corpo no espaço".

Segundo, o espaço não opera apenas como algo a ser internalizado por um corpo ou cérebro para ser utilizado em seu modo de organização nocional e linguístico, ele opera diretamente sobre a cognição.

O espaço não é simplesmente um fundo passivo contra o qual a atividade se desdobra; é algo que pode ser utilizado como um artefato cognitivo. De fato, de acordo com David Kirsh (1995, 1996), distribuições espaciais formam uma parte importante da arquitetura funcional de qualquer sistema de cognição distribuída em pelo menos três aspectos importantes e correlatos: ao apoiar escolha, ao apoiar percepção e ao apoiar resolução de problemas (MALAFOURIS, 2013, p. 72, grifo do autor, tradução nossa).

Assim como objetos materiais, o espaço também é dotado de agência ao distribuir escolhas, percepções e possibilidades de resolução de problemas. Se a subjetividade é uma dobra, um voltar-se sobre si mesma, é também movimento que passa e se dá necessariamente por uma espacialidade material repleta de elementos ativos que a compõem. O Fora é anterior à divisão interno/externo e uma vez que é agenciado, como no caso de uma dobra subjetiva, a linha divisória pode ser estabelecida das mais diversas formas. A ideia de uma subjetividade distribuída faz com que a linha não se dê mais ao redor de um cérebro ou corpo, incorporando a materialidade em toda a sua complexidade e atividade.

A noção de "cognição distribuída" desenvolvida por Hutchins (1995) torna claro o modo pelo qual a cognição, e também a subjetividade, é partilhada entre pessoas, máquinas, espaços e objetos. Ao estudar a vida em um navio da marinha norte-americana e especialmente o modo como é operado, Hutchins (1995) mostra como a cognição que controla o navio não acontece apenas na cabeça dos sujeitos envolvidos, mas se dá "entre" eles. A cognição forma um sistema complexo, que depende de cérebros, corpos, da estrutura física do navio, suas máquinas e também de toda a organização e estrutura militar, que define papeis, fluxos de informação e rivalidades.

Assim como Malafouris (2013), optamos por não dar uma definição precisa ao termo "cognição". No contexto de uma cognição estendida ou distribuída a definição mui- to exata de cognição implica no "princípio de paridade" (CLARK; CHALMERS, 2002), que afirma que um objeto faz parte da cognição ao apresentar propriedades cognitivas, como o bloco de notas que possui características funcionalmente equivalentes à memória humana. $\mathrm{O}$ problema desse princípio é que exclui materialidades e agências que não são "diretamente" cognitivas, além de impor à exterioridade o modelo de um pensamento interiorizado.

Se consideramos a cognição a partir do "princípio de simetria" proposto por Latour (2012) e pela Teoria Ator-Rede, podemos pensar uma mente que não precisa mais ser definida a partir de escolhas binárias que colocam natureza, objetividade, exterioridade e não-humanos de um lado e homem, subjetividade, interioridade de outro. Colocamos humanos e não-humanos no "mesmo nível", quer dizer, ambos são considerados em sua agência própria, e a mente é o "produto" da rede formada pelas ações destes atores. Assim como a cognição, o termo "ator" também é vago, pois não pode ser definido a priori o que um ator é ou não. O ator é quem age, seja uma pessoa, um micróbio, uma divindade ou um pedaço de barro. Não podemos saber de antemão o que pode constituir uma mente, mas a cada novo agenciamento que é composto produzimos novas mentes e formas de subjetividade. Ao analisar alguns traços históricos da memória estendida podemos entender como esse processo de externalização é indissociável da constituição da subjetividade, compondo-se com forças e processos da própria materialidade, chegando à formação das cidades.

Uma das primeiras formas de memória estendida se deu pela voz, pela tradição oral. Enquanto uma mesma narrativa fosse contada e recontada, mesmo sofrendo alterações, ela constituiria um agenciamento capaz de atravessar indivíduos e gerações, similar o fenótipo estendido de Dawkins (ROTMAN, 2008). Mais do que ser a mera transmissão de um conteúdo, gerado primeiramente na interioridade de um sujeito e passando por um canal sonoro para outras interioridades, esta narrativa oral seria, ao invés disso, uma subjetividade que atravessaria inúmeros corpos. Como colocam Clark e Chalmers (2002) a linguagem é como um mar de palavras, um meio que produzidos ao nosso redor para permitir a continuidade e expansão de nossa cognição e pensamento, da mesma maneira que certas espécies de peixe criam turbilhões na água que utilizam para se impulsionar, ao invés de simplesmente se restringirem ao uso de turbilhões existentes.

A ideia de que os pensamentos de um sujeito são invisíveis aos outros, que cada um de nós possui uma interioridade que é completamente fechada aos outros, fora nossas tentativas sempre falhas de transmitir aquilo que pensamos - tudo isto é uma concepção recente na história da espécie humana, tendo um pouco mais de dois mil anos. "Durante a maior parte do processo evolucionário, quase tudo o que indivíduos humanos pensaram e sentiram era tão transparente, que aos outros ao seu redor era como se fossem suas próprias experiências" (SLOTERDIJK, 2011, p. 264, tradução nossa). Os sábios e filósofos na antiguidade foram uns dos primeiros defensores de uma subjetividade indivi- 
dualizada e privada. Ao criar a necessidade de ter "novos" pensamentos, o sábio escapa ao pensamento da tradição, deixando de pensar "como todo mundo".

Uma subjetividade produzida fora de si mesma não é nem uma inovação de um suposto pós-modernismo, nem uma figura da ficção científica. A constituição da subjetividade tornou-se um ato associado a um sujeito individual apenas recentemente, mas nunca conseguiu desligar-se completamente desse componente social e material que lhe acompanha. Ou melhor, como Foucault (1987) mostrou muito bem no caso da prática disciplinar, foi necessário um aparato imenso, e extremamente social e físico, para produzir um sujeito em sua interioridade privada.

A narrativa oral nas sociedades arcaicas, e em todas aquelas que mantiveram essa prática, reflete, em maior ou menor medida, uma subjetividade que atravessa corpos, que não pode ser fechada e resguardada sob a rubrica de um pensamento individual. Em última instância, "cérebros são meios para o que os outros cérebros fazem e fizeram. A inteligência apenas recebe estímulos chave por sua própria atividade com outras inteligências. Como linguagem e emoção, a inteligência não é um sujeito, mas meio ou círculo de ressonância" (SLOTERDIJK, 2011, p. 265, tradução nossa). É nos meios físicos de exteriorização, como a escrita, a pintura e outras formas de inscrição, que encontramos uma segunda forma de exteriorização, que agora torna-se não-humana (ROTMAN, 2008).

A memória seria atribuída a um substrato inerte, como pedra, papel, tecido e outros materiais afins. Em um primeiro momento, a mudança seria possível, de forma ativa, apenas pela ação de um sujeito, que a modificaria ou incrementaria, ou, de forma passiva, pela degradação do material utilizado. A invenção de substratos ativos, de dispositivos capazes de modificar o conteúdo que lhes é inscrito seria uma invenção recente, sendo o computador uma versão mais atual.

O problema desta perspectiva é que coloca a matéria como sendo uma substância externa, passiva em relação ao gesto ativo, para não dizer humano, que lhe dá forma, o que Simondon (2009) chama de "esquema hilemórfico". Este esquema, contudo, oculta o modo de funcionamento próprio à matéria, que revela um meio extremamente complexo e vibrante, permeado de processos não-lineares, auto-organizadores e criativos. Pois se é possível que a matéria se torne, também, memória do homem, é porque a própria matéria já possui uma memória, estreitamente ligada à sua capacidade de auto-organizar, sem precisar tornar-se um ser vivo ou ser atravessada por um impulso vital. Sob a externalização da subjetividade encontramos a externalização da própria matéria.

É necessário distinguir, com a terminologia que Deleuze (2005a) toma de Husserl, entre essências formais e essências morfológicas, isto é, essências exatas e métricas e essências anexatas. As essências formais designam formas perfeitas e exatas, como o círculo ideal, ou o quadrado. É o espaço da geometria euclidiana. Já o redondo é uma essência morfológica, constitui a corporeidade onde nunca há círculo perfeito. Encontramos apenas coisas que são mais ou menos arredondadas, que tendem ao círculo, sem jamais realizá-lo. Por isso podemos falar em essências vagas, ou até mesmo vagabundas, já que possuem sempre algo de indefinido e incerto. A corporeidade é, de um lado, "inseparável dos processos de deformação de qual é a base. Esta é sua primeira característica: ablação, supressão, aumento, passagem ao limite, acontecimentos. E por outra parte, é inseparável de um certo tipo de qualidades suscetíveis de mais e de menos: cor, densidade, peso, etc." (DELEUZE, 2005a, p. 371). Uma subjetividade distribuída é dotada de corporeidade, não de um corpo, naquilo que tem de vaga, vagabunda, em seus processos intensivos, e extensivos. O sujeito descentrado de que falam Deleuze e Guattari (2010) é vagabundo, pois circula incessantemente sobre um corpo-sem-órgãos, sobre uma materialidade e uma corporeidade que não pode ser restrita a um único corpo ou indivíduo.

Ao dar forma a uma matéria, como no caso da modelagem da argila, não se aplica simplesmente um molde a um substrato inerte. A argila tem de ser preparada primeiro, ou seja, tem de se encontrar em certo ponto próprio a suas forças, permitindo que seja capaz de interagir com o molde. Este, por sua vez, ao ser aplicado, sofre também a ação da argila. Como mostra Simondon (2008), o que ocorre de fato não é uma simples modelagem, mas uma modulação, pois ao nível microscópico ocorre uma série de transformações e trocas energéticas, ocasionando diversos estados de equilíbrios e suas passagens, que ao seu final desembocam na forma moldada. Isto se torna mais evidente no caso da metalurgia, pois "o metal é o que nos força a pensar a matéria e nos força a pensá-la como variação contínua, que dizer, como desenvolvimento contínuo da forma e variação contínua da matéria mesma" (DELEUZE, 2005b, p. 378). De matéria inerte e passiva, passamos a concebê-la como variação contínua, como matéria-movimento. Isto nos leva a pensar na matéria de uma forma "não-linear".

Em um sistema linear, para cada causa há um único efeito. Assim como uma linha em um plano cartesiano, para cada ponto existe apenas um par de coordenadas $x \mathrm{e}$ $y$ correspondentes. Com sistemas não-lineares a situação torna-se muito mais complexa, pois para uma mesmo efeito podem existir muitas causas e vice-versa, o que é o caso de processos não determinísticos. Dado o estado atual de um sistema, é muitas vezes impossível saber, mesmo de forma estatística, seus estados anteriores e, principalmente, o estado inicial, caso haja um. Fenômenos não-lineares são, portanto, irreversíveis, como no caso da multiplicação de um número. Dado o número 36, como foi obtido este resultado? Multiplicando 18 por 2,9 por 4,3 por 12 ? Uma vez atingindo certo estado é impossível saber com certeza qual a sua origem, a não ser que todo o processo seja acompanhado de perto, especialmente quando a menor variação pode causar efeitos completamente distintos (o famoso "efeito borboleta"). Em outras palavras, cada sistema ganha uma historicidade, pois sua configuração dependerá sempre de uma ordem muito específica de acontecimentos em um tempo irreversível. Como na 
grande maioria dos casos, tal história não é diretamente acessível tornando o conhecimento de sistemas não-lineares necessariamente estatístico (DELANDA, 2000).

Outro processo capaz de desencadear a não-linearidade de um sistema é a autorreferência, pela qual um sistema, processo ou fluxo pode modificar a si mesmo, tal qual as retroalimentações, em especial a auto-organização. Em uma retroalimentação negativa, como o termostato, o sistema modifica a si mesmo para atingir um equilíbrio homogêneo, voltando a agir sempre que esse equilíbrio é perdido. Com as retroalimentações positivas, o sistema distancia-se de seu equilíbrio, como no efeito estufa, o que produz estados cada vez mais heterogêneos em relação ao estágio inicial. Os efeitos de auto-organização, que são tão característicos dos seres vivos, congregam estes dois processos na medida em que um organismo está sempre buscando um equilíbrio, enquanto modifica-se através de mutações e pressões evolutivas. Contudo, não devemos restringir a auto-organização às formas vivas, pois

[...] até as formas mais humildes de matéria e energia possuem um potencial de auto-organização, para além do tipo relativamente simples envolvido na criação de cristais. Existem, por exemplo, aquelas ondas coerentes chamadas sólitons, que se formam nos mais diferentes tipos de materiais, variando desde águas oceânicas (nas quais são chamadas tsunamis) até lasers. Há, então, os já mencionados estados estáveis (ou atratores), que podem sustentar diferentes tipos de atividades cíclicas (periódicas ou caóticas). Finalmente, e diferentemente dos exemplos anteriores de auto-organização não-linear em que não pode haver verdadeira inovação, existe o que podemos chamar de "combinatória não linear", que explora as diferentes combinações em que podem entrar as entidades derivadas dos processos precedentes (cristais, pulsos coerentes, padrões cíclicos). É a partir dessas combinações ilimitadas que estruturas verdadeiramente inovadoras são geradas. Quando colocadas juntas, todas essas formas de geração estrutural espontânea sugerem que a matéria inorgânica é muito mais variável e criativa do que jamais havíamos imaginado. É este insight acerca da criatividade inerente da matéria que precisa ser inteiramente incorporado em nossas filosofias materialistas (DELANDA, 2000, p. 16, grifo do autor).

A própria matéria é capaz de se organizar, e todos aqueles processos que consideramos como especialmente humanos ou biológicos, como a não-lineariedade, imprevisibilidade, resistência a ação de forças mecânicas e até mesmo a historicidade, já se encontram na matéria. Os registros geológicos, naquilo que têm de irreversível, são a grande memória do mundo. Ao invés da matéria ser uma extensão da cognição e da memória, estas é que são extensões da matéria, nos modos pelos quais, por seu potencial de auto-organização, a matéria dobra a si mesma e pode afetar-se. Uma dessas muitas dobras é o homem, esse mineral que anda e fala, parafraseando Vernadsky (apud BENNETT, 2010).

Uma dobra nunca está completamente isolada de todas as outras, pois dentro de cada dobra podem existir infinitas outras, da mesma maneira que em uma mônada já estão contidas todas as outras, desdobradas em maior ou menor extensão (DELEUZE, 1991). A subjetividade distribuída dobra em si os diversos processos materiais, assume uma corporeidade e assim como a matéria que lhe compõe, complexifica os elementos que agencia. Internalizar e externalizar são os modos pelos quais a matéria é dobrada, em si mesma em outrem, ou mais precisamente, são os modos pelos quais a externalidade e internalidade são "criadas", não existindo nem externalidade nem internalidade absolutas fora dos processos localizados e históricos que as produziram.

No mundo orgânico, por sua vez, tecidos moles (géis e aerossóis, músculos e nervos) reinaram supremos até 500 milhões de anos atrás. Nesse ponto, algumas das conglomerações de carne-matéria-energia que constituam a vida, sofreram uma súbita mineiralização, e um novo material para construir criaturas vivas surgiu: osso. É quase como se o mundo mineral, que servira de substrato para o aparecimento de criaturas biológicas, estivesse reafirmando a si mesmo, confirmando que a geologia, longe de ter sido deixada para trás como um estágio primitivo a evolução da terra, coexistisse plenamente com os moles e gelatinosos recém-chegados. $\mathrm{O}$ osso primitivo, um bastão central duro e calcificado, que mais tarde se tornaria a coluna vertebral, tornou possível novas formas de controle de movimento entre os animais, libertando-os de muitas restrições e literalmente colocando-os em movimento para conquistar todos os nichos disponíveis no ar, na água e no solo. Ainda assim, enquanto o osso permitiu a complexificação do phylum animal ao qual nós, enquanto vertebrados, pertencemos, ele nunca esqueceu sua origem mineral: é o material vivo que mais facilmente petrifica, que mais prontamente cruza o limiar de volta ao mundo das rochas. Por esta razão, muito do registro geológico está escrito em ossos fósseis.

$\mathrm{O}$ endoesqueleto humano foi um dos muitos produtos desta antiga mineiralização. Contudo, não é a única infiltração geológica que a espécie humana sofreu. Cerca de oito mil anos atrás, populações humanas começaram a se mineiralizar novamente quando desenvolveram um exoesqueleto urbano: tijolos de argila secada no sol tornaram-se os materiais de construção de suas casas, que por sua vez cercaram e foram cercadas por monumentos de pedra e muralhas defensivas. Este exoesqueleto servia a um propósito similar a sua contraparte interna: controlar o movimento de entrada e saída de carne humana pelas muralhadas da cidade. $\mathrm{O}$ exoesqueleto urbano controlava também o movimento de muitas outras coisas: objetos de luxo, notícias e comida, por exemplo (DELANDA, 2000, p. 26-27, grifo do autor, tradução nossa).

A cidade aparece como um dos mais importantes elementos da externalização humana. Considerar a cidade como um exoesqueleto não constitui uma simples metáfora, pois como vimos no caso do fenótipo estendido e da cognição distribuída ao mudar o foco de nossa análise de grupos e indivíduos para as forças que os atravessam, a cidade passa a ser não um produto inerte do ambiente, mas um elemento ativo da composição das mais diversas subjetividades. 


\section{A cidade}

Como podemos pensar a cidade, de um lado, da perspectiva de uma corporeidade vaga, de uma matéria em variação contínua e, do outro lado, em relação com dobras e subjetividades distribuídas? A cidade, como pensa DeLanda (2006), diferentemente de redes e organizações, não pode ser definida sem sua relação com o espaço, apesar de não se limitar à dimensão espacial. Organizações e redes, por conta das tecnologias de comunicação, podem ser constituídas sem ligação a uma espacialidade específica. A cidade, contudo, não existe fora de um espaço específico, mesmo nos casos de conurbação onde as fronteiras entre cidades tornam-se vagas (desaparecendo completamente a divisão cidade e campo). Neste espaço, uma cidade está sujeita a "processos centrípetos, como a captura de população, investimento e outros recursos, assim como forças centrífugas, como congestão, poluição, tráfico. No ponto de virada, quando um conjunto de forças começa a dominar o outro, uma cidade pode crescer explosivamente ou encolher como uma sombra de sua antiga estatura" (DELANDA, 2006, p. 108, tradução nossa). Por fim, uma cidade pode organizar-se a partir de hierarquias, como as burocracias, ou malhas, como os mercados.

Adentrar o espaço da cidade não constitui a experiência de um sujeito cartesiano que circula por uma extensão homogênea, exata e precisa. $\mathrm{O}$ espaço da cidade é vago, é anexato. As medidas - quando há medida - transformam-se de acordo com os processos e acontecimentos que afetam aquele momento. Se o espaço é dotado de agência, se coloca problemas e participa de forma ativa de nossa cognição e subjetividade, não é possível simplesmente "entrar" no espaço de uma cidade. Tal entrada é necessariamente uma composição, uma mistura que coloca em jogo muito mais do que meras dimensões métricas. Espaço e corpo são acoplados, transformam-se mutualmente, e tal jogo constitui cognições e subjetividade distribuídas. Uma cidade, de acordo com suas forças de crescimento e encolhimento, assim como seus modos de organização, pode ser atravessada por linhas de exclusão muito claras e precisas, que definem sem sombra de dúvida quem pode circular ou não naquele espaço. Em outros momentos, as linhas tornam-se borradas, ou mudam constantemente (DELANDA, 2006).

As hierarquias definem-se por uma organização de cima para baixo, que tenta controlar de forma centralizada os fluxos e movimentos de uma cidade. A malha, por sua vez, é organizada de baixo para cima, constituindo-se como propriedade emergente dos elementos em interação. Uma cidade é uma mistura em maior ou menor grau destes dois modos de organização. Em ambos os casos se concebe a cidade como fluxo, passagem de matéria, energia, pessoas, bens, memórias e cognições (DELANDA, 2000). "As cidades são como transformadores elétricos: aumentam as tensões, caldeiam constantemente a vida dos homens" (BRAUDEL, 1995, p. 439) - e dos não-humanos também. "A cidade é corte, ruptura, destino do mundo" (BRAUDEL, 1995, p. 439). A cidade corta e faz fluir, atravessa e é atravessada.
Como então pensar a relação entre cidade e subjetividade distribuída? Se o modelo de subjetividade que propomos não pode mais ser atribuído, necessariamente, a um corpo, como é possível se relacionar com a cidade ou, mais precisamente, desta se diferenciar? Em relação a qual cidade? Se considerarmos a sociedade disciplinar, a cidade é atravessada por instituições e práticas que buscam individualizar, treinar, docilizar e vigiar corpos, transformando-os em sujeitos dóceis e individuais. Para este procedimento o espaço tem uma importância fundamental, já que tal individualização depende da repartição cuidadosa dos locais, para que cada corpo se encontre separado de todos os outros e, preferencialmente, classificados e dispostos de acordo com suas forças e capacidades. Há uma divisão clara entre sujeito e não-sujeito, humano e não-humano. É aí que encontramos o modelo da casa burguesa, cuidadosamente subdivida em cômodos que devem, cada um, cumprir funções individualizadoras específicas (FOUCAULT, 1987).

Mesmo sob todos estes processos de individualização, a subjetividade ainda opera de modo distribuído. Não é por acaso que foi neste mesmo período que a noção de inconsciente, tanto em Nietzsche quando na psicanálise, começou a ser trabalhada. O inconsciente freudiano não é um mero aglomerado de memórias inertes que aguardam o momento de serem relembradas. Há uma divisão, uma barreira que impede seu acesso, ao mesmo tempo em que tais memórias continuam a agir, junto com desejos e pulsões. A relação que se estabelece entre consciência e memória em uma subjetividade distribuída é da mesma ordem do inconsciente. Existem memórias que continuam agindo e se transformando, para além da consciência do indivíduo e que este não tem acesso. Contudo, diferentemente da psicanálise, tal divisão não se dá no interior do sujeito, pois pouco importa onde se encontram tais memórias. Podem estar registradas em seus neurônios, em um livro de infância que continua a circular nas mãos de outras crianças ou na memória de outros corpos. É um inconsciente muito mais maquínico do que edipiano. (DELEUZE; GUATTARI, 2010)

A cidade torna-se a superfície de inscrição de tais memórias, assim como fonte de cognição ativa, com seus fluxos intermináveis, incluindo fluxos de processamento de informação, imagens, sensações e ações. Externalizar a cognição, equivale a delegar o pensamento a fontes fora do corpo individual, abrindo espaço para outras cognições. Mais precisamente, "a cognição é algo que circula". E como fluxo torna-se indissociável de uma micropolítica, dos modos pelos quais os fluxos e devires são agenciados, controlados, potencializados. A cognição deixa de ser um mero ato de processamento de informação representacional do indivíduo para existir como força que participa ativamente de dominações e exclusões, que é dividida e repartida de acordo com classes, raças, gêneros, recursos. A subjetividade distribui-se pela cidade, mas não pode fazê-lo de "qualquer modo". A dominação limita e direciona a proliferação de subjetividades, impede sua distribuição e a coloca sob canais controlados. A 
resistência passa, muitas vezes, pelo simples ato de circular, de compor com um espaço que não é o seu. Tomar e ser tomado pelas ruas.

Por exemplo, o supermercado pelo qual você passa em frente todo dia sempre coloca o valor de certos produtos em promoção em exposição. Este processamento de informação equivaleria a ação de um indivíduo que sai de seu caminho, entra no supermercado, e vê, produto por produto qual a promoção do dia. O sujeito, em seu andar cotidiano, não desejou nem pediu para que tal valor fosse exposto, na mesma medida em que o Eu consciente não pede, nem espera aquilo que age em seu inconsciente. Esse pequeno gesto, de expor um valor, passa a fazer parte dos processos cognitivos dos sujeitos que por ele passam, seja para considerar a possibilidade compra, seja para ignorá-lo.

Experiência muito distinta seria a de um morador de rua que vive em frente ao supermercado, que também circula em meio aos mesmos signos. A divisão atravessa diretamente a cognição e subjetividade, pois para ele não existe a escolha entre comprar ou não tal produto, não pode fazer parte de tal sistema. Sua subjetividade é atravessada por outros elementos, é uma cognição composta por restos de comida, latas de lixo, latinhas para vender e o cálculo dos perigos que enfrenta todo dia.

A vida na cidade é composta por essas pequenas rotinas, por esses hábitos (DELEUZE, 2006). Os caminhos que são feitos, os eventuais desvios e mudanças inesperadas, toda a pletora de signos, sons, movimentos, sinalizações e indícios que são encontrados pelo caminho, assim como as pessoas e suas atividades, tudo isto constitui uma subjetividade distribuída. O sujeito "é tudo isso", é o espaço não que atravessa, mas que agencia e pelo qual é agenciado. Subjetividade composta pelas diversas matérias em suas variações contínuas, nas propriedades energéticas que conservam sinais os tornam lembranças, ou que os deterioram em esquecimentos; pelas forças de organização e desorganização da cidade, suas hierarquias e malhas; pelas pessoas e suas vozes, gestos e subjetividades também distribuídas. Pensar a subjetividade distribuída "na" cidade é pensar a própria cidade, que deixa de ser um aglomerado de forças mais ou menos inertes, mais ou menos ativas, para se tornar esse "destino do mundo" de que fala Braudel (1995), isto é, esta mistura incessantemente de humanos e não-humanos, de vida e de matéria inorgânica, de ordem e caos.

\section{Referências}

AGAMBEN, G. Homo Sacer. Belo Horizonte: UFMG, 2002.

BENNETT, J. Vibrant Matter: a political ecology of things. London: Duke University Press, 2010.

BRAUDEL, F. Civilização material, economia e capitalismo, séculos XV-XVIII: as estruturas do cotidiano. São Paulo: Martins Fontes, 1995.

CARDOSO FILHO, C. A. Ceticismo e ingenuidade: a problematização da subjetividade no pensamento de Foucault, Deleuze e Guattari. Florianópolis: UFSC, 2011.
CLARK, A; CHALMERS, D. The extended mind. In: CHALMERS, D. (Org.). Philosophy of mind: classical and contemporary readings. Oxford: Oxford University Press, 2002. p. 643-652.

DAWKINS, R. The extended phenotype. New York: Oxford University Press, 2008.

DELANDA, M. A new philosophy of society: assemblage theory and social complexity. New York: Bloomsbury Academic, 2006

DELANDA, M. A thousand years of nonlinear history. New York: Swerve, 2000.

DELEUZE, G. A dobra: Leibniz e o Barroco. Campinas: Papirus, 1991.

DELEUZE, G. Sobre quatro fórmulas poéticas que poderiam resumir a filosofia kantiana. In: Crítica e Clínica. São Paulo: Ed. 34, 1997. p. 36-44.

DELEUZE, G. Derrames: entre el capitalismo y la esquizofrenia. Buenos Aires: Cactus: 2005a.

DELEUZE, G. Foucault. São Paulo: Brasiliense, 2005b.

DELEUZE, G. Diferença e repetição. Rio de Janeiro: Graal, 2006.

DELEUZE, G.; GUATTARI, F. O Anti-Édipo. São Paulo: Ed. 34,2010

DESCARTES, R. Discurso do método; As paixões da alma; Meditações. São Paulo: Nova Cultural, 2000.

FOUCAULT, M. Vigiar e punir. Petrópolis, RJ: Vozes, 1987.

HUTCHINS, E. Cognition in the wild. Cambridge: MIT, 1995.

KANT, I. Crítica da Razão Pura. São Paulo: Nova Cultural, 2000.

KLINE, M. Mathematics: the loss of certainty. Oxford: Oxford University Press, 1982.

LATOUR, B. Reagregando o social. Salvador: Edufba, 2012.

MALAFOURIS, L. How things shape the mind. Cambridge: MIT, 2013.

ROTMAN, B. Becoming beside ourselves. London: Dukre University Press, 2008

SIMONDON, G. La Individuación. Buenos Aires: La Cebra y Cactus, 2009.

SLOTERDIJK, P. Spheres: Bubbles. Los Angeles: Semiotext(e), 2011. v. 1 .

VARELA, F.; THOMPSON, E.; ROSCH, E. The embodied mind. Cambridge: MIT, 1993.

Recebido em: 17 de março de 2015 Aceito em: 7 de julho de 2016 